\title{
dKEPUASAN SISWA TERHADAP PENGGUNAAN GOOGLE CLASSROOM SEBAGAI MEDIA PEMBELAJARAN PENJAS SMP NEGERI 18 PONTIANAK
}

\author{
Edi gunawan,Andika triansyah,Fitriana puspa hidasari \\ Program studi pendidikan jasmani FKIP Untan Pontianak \\ Email:f1101151011@student.untan.ac.id
}

\begin{abstract}
Distance learning during the COVID-19 pandemic poses several obstacles for students, especially in physical education subjects. Learning solutions that can be used to support the learning process are online. One of the platforms used in the online learning process is Google Classroom which contains features that support so that teaching and learning activities are more effective. This research is a descriptive research conducted by survey method and the instrument used is a questionnaire. The purpose of this study was to determine student satisfaction with the use of google classroom as a physical education learning medium during the covid-19 pandemic, the subjects of this study were class VIII students at SMP Negeri 18 Pontianak. Test the validity of the instrument using Product Moment Correlation and test the reliability of the instrument using the Alpha Cronbach formula through SPSS V25. The validity coefficient is 0.374 and the coefficient is 0.942 and to analyze the data used quantitative descriptive techniques with percentages. Based on the results of research conducted by researchers with a total population of 203 people while those who answered the questionnaire were 139 people, the following results were obtained: there were 11 students $(7.91 \%)$ in the "very satisfactory" category, there were 39 students (28.06\%) ) in the "satisfactory" category, and 81 students (58.28\%) in the "unsatisfactory" category, while 8 students (5.75\%) were classified as "very unsatisfactory". Student satisfaction with the use of Google Classroom as a physical education learning medium during the Covid-19 pandemic class VIII at SMP Negeri 18 Pontianak was in the "unsatisfactory" category.
\end{abstract}

Keyword : Google Classroom, Satisfaction, Student, Survey

\section{PENDAHULUAN}

Kementerian Pendidikan Indonesia mengeluarkan Surat Edaran Mendikbud No. 4 Tahun 2020 tentang "Pelaksanaan Kebijakan dan Pendidikan Dalam Masa Darurat Penyebaran Corona Virus Disease (Covid-19)" dengan meliburkan dan mengganti proses Kegiatan Belajar Mengajar (KBM) di sekolah dengan menggunakan sistem dalam jaringan (daring) di rumah. Pembelajaran daring, online, atau pembelajaran jarak jauh bertujuan untuk memenuhi standar pendidikan dengan pemanfaatan teknologi informasi dengan menggunakan perangkat komputer atau gadget yang saling terhubung dengan siswa dan guru maupun mahasiswa dengan dosen.
Teknologi membuat siswa tetap terhubung dengan guru sehingga transfer ilmu tetap dapat dilaksanakan dengan baik. Teknologi yang dapat dimanfaatkan untuk melakukan pembelajaran ini adalah telepon seluler maupun komputer yang bisa terhubung dengan internet. Peran teknologi yang ada saat ini berguna sebagai media pembelajaran, salah satunya adalah flatform google classroom.

Kusuma dan Astuti mengungkapkan bahwa (Kusuma dan Astuti 2019) google classroom menyediakan fitur forum diskusi sehingga pengajar bisa membuka sebuah diskusi kelas yang bisa ditanggapi dan dikomentari seperti aktivitas berkomentar 
di facebook"(p.78). Sedangkan menurut Corbyn (2019) juga menjelaskan google classroom atau ruang kelas google merupakan "suatu sarana media pembelajaran campuran untuk ruang lingkup pendidikan yang dapat memudahkan pengajar dalam membuat, membagikan dan menggolongkan setiap penugasan tanpa kertas (paperless)."'(p.13).

Hal ini yang dapat dimanfaatkan oleh guru, siswa dan wali murid dalam pembelajaran, sehingga tidak diperlukan kerjasama dengan google. Ini menunjukan bahwa "Pemanfaatan secara terbuka dapat memberikan keuntungan bagi pengguna google classroom"'(Grossman, 2013,p.56).

Kepuasan merupakan tanggapan perasaan seseorang terhadap kebutuhan yang dialami dengan harapan yang di inginkan oleh seseorang. Sedangkan kepuasan siswa adalah suatu sikap yang diperlihatkan oleh siswa baik sikap positif maupun sikap negatif atas adanya kesesuaian harapan siswa terhadap proses belajar yang diterima. Jika proses pembelajaran pendidikan jasmani yang diterima siswa sesuai dengan apa yang diharapkan, maka siswa akan cenderung merasa puas dan jika pembelajaran yang diterima tidak sesuai dengan harapan siswa, maka siswa cenderung akan merasa kurang puas.

Sedangkan Oliver yang dikutip Udiutomo (2011) menyatakan bahwa "kepuasan merupakan penilaian konsumen terhadap fitur-fitur produk atau jasa yang berhasil memberikan pemenuhan kebutuhan pada level yang menyenangkan baik itu di bawah maupun di atas harapan"(p.7). Sejalan dengan Wijaya (2011) menyatakan bahwa, "kepuasan adalah tanggapan pelanggan atas terpenuhinya kebutuhan" (p.153).

SMP N 18 Pontianak juga menerapkan kebijakan belajar dari rumah kepada seluruh peserta didiknya. Hal ini dikarenakan kota Pontianak, Kalimanta Barat merupakan salah satu wilayah yang juga terdapat penularan Covid-19 sehingga segala macam aktivtas kegiatan harus dilakukan dari jarak jauh. Pendidik dan peserta didik dari SMP N 18 Pontianak juga mengunakan google classroom sebagai media pembelajaran jarak jauh sejak tanggal 27 Juni 2020 sampai sekarang. Khususnya untuk mata pelajaran pendidikan jasmani bagi kelas VIII SMP N 18 Pontianak yang jumlah peserta didik kelas VIII yaitu 203 orang. Berbagai kendala di hadapi siswa terutama dalam mata pelajaran pendidikan jasmani karena pada dasarnya didominasi oleh aspek psikomotorik (keterampilan fisik). Di dalam praktikumnya siswa terbatas dalam melakukan gerakan dikarenakan tempat yang kurang mendukung, selain itu daya serap siswa dalam mempelajari materi tidak semudah dengan apa yang dilihat.

Siswa membutuhkan waktu untuk beradaptasi dalam menghadapi perubahan baru yang secara tidak langsung akan mempengaruhi daya serap belajar baik dalam teori maupun praktikumnya, Seperti tidak semua siswa memiliki smartphone sehingga tugas harus langsung diambil ke sekolah, koneksi internet yang tidak setabil, kurangnya pengetahuan siswa tentang google classroom, siswa juga mengalami kesulitan dalam pembelajaran yang seharusnya dilakukan dilapangan diubah menjadi membuat video praktek dengan durasi 5 menit.

Terlebih pembelajaran jarak jauh ditujukan kepada siswa untuk tetap dapat memahami materi pelajaran. Sehingga perlu diadakan pengkajian lebih dalam terkait kepuasan siswa dalam melakukan pembelajaran jarak jauh menggunakan Google Classroom di tengah pandemi covid-19 agar pembelajaran yang di berikan oleh guru melalui Google Clasroom dapat di pahami oleh siswa dengan baik.

\section{Penelitian Relevan}

Dany Dwi Setyawan 2014 yang berjudul "tingkat kepuasan siswa kelas atas terhadap sarana dan prasarana pendidikan jasmani di SD Negeri Lempuyangan 1 Yogyakarta" dapat 
disimpulkan bahwa terdapat 29 siswa $(18,8 \%)$ dalam kategori "sangat memuaskan", terdapat 95 siswa $(61,7 \%)$ dalam kategori "memuaskan", dan 30 siswa (19,5\%) dalam kategori "cukup memuaskan", sedangkan tidak ada siswa $(0 \%)$ yang tergolong dalam kategori "tidak memuaskan" dan "sangat tidak memuaskan". Sehingga dari deskripsi atau sebuah gambaran secara umum dapat disimpulkan bahwa tingkat kepuasan siswa kelas atas terhadap penggunaan sarana dan prasarana pendidikan jasmani di SD Negeri Lempuyangan 1 Yogyakarta berada pada kategori "memuaskan"

\section{METODE PENELITIAN}

Penelitian ini termasuk kedalam penelitian deskriptif kuantitatif dengan metode survey (Sugiyono, 2018). Metode survey yang didukung dengan istrumen penelitian berupa angket. Angket yang digunakan dalam penelitian ini adalah angket tipe pernyataan, artinya memberikan seperangkat daftar pernyataan melalui google form.
Penggunaan google form dikarenakan penetapan kegiatan belajar mengajar secara daring, sehingga responden dapat mengii angket dimanapun dan kapanpun mereka berada. Penelitian ini dilaksanakan pada taggal 04 hingga 24 mei 2021 yang berlokasi di SMP Negeri 18 Pontianak. Populasi dalam penelitian ini adalah peserta didik kelas VIII SMP Negeri 18 Pontianak yang berjumlah 203 siswa/i dengan sampel 139 siswa untuk menggeneralisir dengan ditingkat kesalahan $5 \%$.

Penelitian ini dimulai dari pengujian instrumen secara validitas dan reliabilitasnyadengan menggunakan angket yang di lakukan di SMP Negeri 18 pontianak kelas VII ini memiliki karakteristik yang sama dengan SMP Negeri 18 Pontinanak kelas VIII.

Langkah selanjutnya peneliti menguji data validitas dan reliabilitasnya menggunakan aplikasi SPSS 25.0. kemudian setelah semua pertanyaan angket selesai diuji, peneliti menyeleksi pertanyaan tersebut dan dilakukannya pengambilan data yang sesungguhnya di SMP Negeri 18 Pontianak khusus kelas VIII.

Tabel 1. Hasil uji validitas istrument

\begin{tabular}{lccc}
\hline \multicolumn{4}{c}{ Habel 1. Hasil uji validitas istrument } \\
\hline No Item & R Table & R Hitung & Keterangan \\
\hline X01 & 0,374 & 0,315 & Tidak Valid \\
\hline X02 & 0,374 & 0,194 & Tidak Valid \\
\hline X03 & 0,374 & 0,546 & Valid \\
\hline X04 & 0,374 & 0,615 & Valid \\
\hline X05 & 0,374 & 0,837 & Valid \\
\hline X06 & 0,374 & 0,585 & Valid \\
\hline X07 & 0,374 & 0,700 & Valid \\
\hline X08 & 0,374 & 0,761 & Valid \\
\hline X09 & 0,374 & 0,379 & Valid \\
\hline X10 & 0,374 & 0,641 & Valid
\end{tabular}




\begin{tabular}{llll}
\hline \multicolumn{3}{c}{ Hasil Uji Validitas } \\
\hline X11 & 0,374 & 0,817 & Valid \\
\hline X12 & 0,374 & 0,587 & Valid \\
\hline X13 & 0,374 & 0,681 & Valid \\
\hline X14 & 0,374 & 0,673 & Valid \\
\hline X15 & 0,374 & 0,670 & Valid \\
\hline X16 & 0,374 & 0,417 & Valid \\
\hline X17 & 0,374 & 0,682 & Valid \\
\hline X18 & 0,374 & 0,727 & Valid \\
\hline X19 & 0,374 & 0,009 & Tidak Valid \\
\hline X20 & 0,374 & 0,650 & Valid \\
\hline X21 & 0,374 & 0,358 & Tidak Valid \\
\hline X22 & 0,374 & 0,611 & Valid \\
\hline X23 & 0,374 & 0,812 & Valid \\
\hline X24 & 0,374 & 0,632 & Valid \\
\hline X25 & 0,374 & 0,731 & Valid \\
\hline X26 & 0,374 & 0,804 & Valid \\
\hline
\end{tabular}

Kriteria penilaian butir soal yang valid apabila nilai $r$ hitung $>r$ tabel $(0,374)$ dan jika $r$ gitug $<r$ tabel maka dinyatakan gugur (Tidak Valid), dengan taraf signifikan yang digunakan 5\%. Berdasarkan hasil uji validitas yang di berikan ke sebagian siswa/i kelas VII di SMP Negri 18 Pontianak yang berjumlah 30 orang dengan 26 butir soal, terdapat 4 butir soal yang gugur yaitu nomor $1,2,19$, dan 21 sehingga terdpat 22 butir soal yang dinyatakan valid untuk mengambil data penulisan

Kepuasan siswa terhadap penggunaan google classroom sebagai media pembelajaran pendidikan jasmani pada masa pandemi covid-19 kelas VIII di
SMP Negeri 18 Pontianak secara daringg diukur berdasarkan 5 faktor yaitu imbalan hasil belajar, rasa aman dalam pelaksanaan belajar, kondisi belajar siswa, kesempatan siswa mengembangkan diri, dan hubungan pribadi. Data yang dikumpulkan berupa data kuantitatif, dengan rincian berupa angka yang menghasilkan persentase, angket di sebarkan melalui group whatsapp kelas VIII SMP Negeri 18 Pontianak berupa link google form. instrumen pertanyaan terdiri dari 22 yang setelah diuji validitas dan reliabilitasnya sehingg memiliki tinggkat reliabilitas sebesar 0,942. Berikut adalah kisi-kisi butir pertanyaan angket 
Tabel. 2 kisi-kisi pertanyaan

\begin{tabular}{cll}
\hline No & \multicolumn{1}{c}{ faktor } & deskripsi \\
\hline 1 & imbalan hasil belajar & $\begin{array}{l}\text { sesuatu yang diperoleh siswa sebagai konsekuensi dari } \\
\text { perilaku belajar yang secara formal dinyatakan dalam } \\
\text { bentuk nilai-nilai dari hasil belajar melalui google } \\
\text { classroom }\end{array}$ \\
\hline 2 & $\begin{array}{l}\text { rasa aman dalam pelaksanaan } \\
\text { belajar }\end{array}$ & $\begin{array}{l}\text { tidak mengalami kesulitan dan gangguan dari luar dalam } \\
\text { menggunakan google classroom }\end{array}$ \\
\hline 3 & kondisi belajar siswa & $\begin{array}{l}\text { belajar dalam kondisi fisik dan sosial yang baik saat } \\
\text { menngunakan google classroom }\end{array}$ \\
\hline 4 & $\begin{array}{l}\text { kesempatan siswa } \\
\text { mengembangkan diri }\end{array}$ & $\begin{array}{l}\text { kesempatan untuk melanjutkan ke perguruaan tinggi, } \\
\text { kenaikan kelas dan ke bebasan dalam menemukakan } \\
\text { pendapat dalam menggunkan google classroom }\end{array}$ \\
\hline 5 & hubungan pribadi & $\begin{array}{l}\text { terciptanya hubungan antra pribadi dalam lingkungan } \\
\text { sekolah saat belajar menggunakan google classroom }\end{array}$ \\
\hline
\end{tabular}

Tabel 3. Butir petanyaan angket

\begin{tabular}{clcc}
\hline No & \multicolumn{1}{c}{ faktor } & No.pernyataan & Jumlah \\
\hline 1 & imbalan hasil belajar & $1,2,3$ & 3 \\
\hline 2 & $\begin{array}{l}\text { rasa aman dalam pelaksanaan } \\
\text { belajar }\end{array}$ & $4,5,6,7,8$ & 5 \\
\hline 3 & kondisi belajar siswa & $9,10,11,12,13,14$ & 6 \\
\hline 4 & $\begin{array}{l}\text { kesempatan siswa } \\
\text { mengembangkan diri }\end{array}$ & $15,16,17$ & 3 \\
\hline 5 & hubungan pribadi & $18,19,20,21,22$ & 5 \\
\hline
\end{tabular}

Teknik yang dipergunakan dalam penelitian ini adalah deskriptif kuantittatif

\section{HASIL PENELITIAN DAN PEMBAHASAN \\ Hasil}

Hasil analisis data menunjukan kepuaan siswa terhadap penggunaan google classroom sebagai media pembelajaran pendidikan jasmani pada masa pandemi covid-19 kelas VIII di SMP Negeri 18 Pontianak tahun 2021 masuk dalam kategori "sangat memuaskan" $7,91 \%$ atau
11 siswa, kategori memuaskan persentase $28,06 \%$ atau 39 siswa, kategori tidak memuaskan perentase $58,28 \%$ atau 81 siswa, kategori sangat tidak memuaskan persentase $5,75 \%$ atau 8 siswa. hasil tersebut di artikan kepuasan siswa terhadap penggunaan google classroom sebagai media pembelajaran pendidikan jasamani pada masa pandemi covid-19 kelas VIII di SMPN 18 pontianak tahun 2021 menyatakan Tidak Memuaskan. Berikut adalah rincian data hasil penelitian berdasarkan masing-masing faktor

Tabel 4. Hasil faktor imbalan hasil belajar

\begin{tabular}{cccc}
\hline Interval & Kategori & Jumlah & Persentase (\%) \\
\hline $12 \geq 11,38$ & Sangat Memuaskan & 24 & $17,26 \%$ \\
\hline $9,97 \leq \mathrm{X}<11,38$ & Memuaskan & 87 & $62,59 \%$ \\
\hline $7,18 \leq \mathrm{X}<9,97$ & Tidak Memuaskan & 20 & $14,39 \%$ \\
\hline $4 \leq 7,18$ & Sangat Tidak Memuaskan & 8 & $5,76 \%$ \\
\hline
\end{tabular}




\begin{tabular}{cccc}
\hline Interval & Kategori & Jumlah & Persentase (\%) \\
\hline & Jumlah & 139 & 100 \\
\hline
\end{tabular}

Tabel 5. Hasil faktor rasa aman dalam pelaksanaan belajar

\begin{tabular}{cccc}
\hline Interval & Kategori & Jumlah & Persentase (\%) \\
\hline $20 \geq 18,74$ & Sangat Aman & 29 & $20,86 \%$ \\
\hline $16,83 \leq \mathrm{X}<18,74$ & Aman & 47 & $33,81 \%$ \\
\hline $12,06 \leq \mathrm{X}<16,83$ & Tidak Aman & 55 & $39,57 \%$ \\
\hline $9 \leq 12,06$ & Sangat Tidak Aman & 8 & $5,76 \%$ \\
\hline & Jumlah & 139 & 100 \\
\hline
\end{tabular}

Tabel 6. Hasil faktor kondisi belajar siswa

\begin{tabular}{cccc}
\hline Interval & Kategori & Jumlah & Persentase (\%) \\
\hline $24 \geq 23,52$ & Sangat Memuaskan & 20 & $14,39 \%$ \\
\hline $20,63 \leq \mathrm{X}<23,52$ & Memuaskan & 44 & $31,65 \%$ \\
\hline $14,85 \leq \mathrm{X}<20,63$ & Tidak Memuaskan & 68 & $48,92 \%$ \\
\hline $9 \leq 14,85$ & Sangat Tidak Memuaskan & 7 & $5,04 \%$ \\
\hline & Jumlah & 139 & 100 \\
\hline
\end{tabular}

Tabel 7. Hasil faktor kesempatan siswa mengembangkan diri

\begin{tabular}{cccc}
\hline Interval & Kategori & Jumlah & Persentase (\%) \\
\hline $12 \geq 11,63$ & Sangat Memuaskan & 34 & $24,46 \%$ \\
\hline $10,17 \leq \mathrm{X}<11,63$ & Memuaskan & 29 & $20,86 \%$ \\
\hline $7,26 \leq \mathrm{X}<10,17$ & Tidak Memuaskan & 72 & $51,80 \%$ \\
\hline $5 \leq 7,26$ & Sangat Tidak Memuaskan & 4 & $2,88 \%$ \\
\hline & Jumlah & 139 & 100 \\
\hline
\end{tabular}

Tabel 8. Hasil faktor hubungan pribadi

\begin{tabular}{cccc}
\hline Interval & Kategori & Jumlah & Persentase (\%) \\
\hline $20 \geq 19,14$ & Sangat Memuaskan & 17 & $12,23 \%$ \\
\hline $16,78 \leq \mathrm{X}<19,14$ & Memuaskan & 48 & $34,53 \%$ \\
\hline $12,07 \leq \mathrm{X}<16,78$ & Tidak Memuaskan & 66 & $47,48 \%$ \\
\hline $10 \leq 12,07$ & Sangat Tidak Memuaskan & 8 & $5,76 \%$ \\
\hline
\end{tabular}




\begin{tabular}{cccc}
\hline Interval & Kategori & Jumlah & Persentase (\%) \\
\hline & Jumlah & 139 & 100 \\
\hline
\end{tabular}

\section{Pembahasan}

Kepuasan siswa terhadap penggunaan google classroom sebagai media pembelajaran pendidikan jasmani pada masa pandemi covid-19 kelas VIII di SMP Negeri 18 Pontianak di pengaruhi beberpa faktor sebagai berikut:

1. Imbalan hasil belajar

Berdasarkan hasil analisis, diketahui kepuasan siswa terhadap penggunaan google classroom sebgai media pembeljaran pendidikan jasamani pada masa pandemi covid-19 pada kelas VIII SMPN 18 Pontianak untuk faktor imbalan hasil belajar dalam kategori sangat memuaskan perentase $17,26 \%$ atau 24 siswa, kategori memuasakn persentase $62,59 \%$ atau 87 siswa, kategori tidak memuaskan persentase $14,39 \%$ atau 20 siswa, kategori sangat tidak memuasakan persentase $5,76 \%$ atau 8 siswa. Berdasarkan Sopiatin (2010) imbalan hasil belajar merupakan sesuatu yang diperoleh siswa sebagai konsekuensi dari perilaku belajar yang secara formal dinyatakan dalam bentuk nilai-nilai dari hasil belajar (p.55).

2. Rasa aman dalam pelaksanaan belajar

Hasil analisis kepuasan siswa terhadap penggunaan google classroom untuk faktor rasa aman dalam pelaksanaan belajar masuk dalam kategori sangat aman persentase $20,86 \%$ atau 29 siswa, kategori aman persentase $33,81 \%$ atau 47 siswa, kategori tidak aman persentase $39,57 \%$ atau 55 siswa, dan kategori sangat tidak aman persentase $5,67 \%$ atau 8 siswa. Hal ini karena rasa aman dalam pelaksanaan belajar salah satunya berupa gangguan pada jaringan internet. Berdasarkan Sopiatin (2010) rasa aman dalam belajar merupakan kondisi tidak adanya kesulitan daan gangguan dari luar (p.55).
3. Kondisi belajar siswa

Analisis kepuasan siswa terhadap penggunaan google classroom untuk faktor kondisi belajar siswa masuk dalam kategori sangat memuaskan persentase $14,39 \%$ atau 20 siswa, kategori memuaskan persentase $31,65 \%$ atau 44 siswa, kategori tidak memuaskan persentase $48,92 \%$ atau 64 siswa, kategori sangat tidak memuaskan persentase $5,04 \%$ atau 7 siswa. karena kondisi belajar salah satunya berupa waktu belajar dirumah. Berdasarkan Sopiatin (2010) kondisi belajar merupakan tidak menggalami kesulittan dan gangguan dari luar (p.55).

4. Kesempatan siswa menembangkan diri

Analisis kepuasan siswa terhadap penggunaan google classroom untuk faktor kesempaan siswa mengembangkan diri masuk dalam kategori sangat memuaskan persentase $24.46 \%$ atau 43 siswa, kategori memuaskan persentase $20,86 \%$ atau 29 siswa, kategori tidak memuaskan persentase $51,80 \%$ atau 72 siswa, kategori sangat tidak memuaskan persentase $2,88 \%$ atau 4 siswa. Hal ini karena kesempatan siswa mengembangkan diri salah satunya berupa hasil dari tugas dan uts yang diberikan oleh guru. Berdasarkan Sopiatin (2010) kesempatan siswa mengambangkan diri ini misalnya kesempatan melnjutkan keperguruan tinggi, kenaikan kelas, dan bebas dalam mengemukakan pendapat(p.55).

5. Hubungan pribadi

Analisis kepuasan siswa terhadap penggunaan google classroom untuk faktor hubunngan pribadi masuk dalam kategori sangat memuaskan persentase $12,23 \%$ atau 17 siswa, kategori memuaskan persentase $34,53 \%$ atau 48 siswa, kategori tidak memuaskan 
persentase $47,48 \%$ atau 66 siswa, kategori sangat tidak memuaskan persentase $5,76 \%$ atau 8 siswa. Hal ini karena hubungan pribadi salah satunya berupa pemanfaatan flatform google classroom sebagai media pembelajaran dan komunikasi siswa dan guru. Berdasarkan Sopiatin (2010) hubungan pribadi merupakan suasana terciptanya hubunan antara pribdi dalam lingkungan sekolah(p.55).

Hasil tersebut diartikan bahwa sebagian besar peserta didik kelas VIII menyatakan pembelajaran pendidikan jasmani secara daring belum sepenuhnya efektif dan positif. Dikarenakan pendidikan jasmani yang biasanya dilakukan diruang terbuka dengan berbagai aktivitas fisik harus mengikuti pembelajaran daring.

Sehingga mengakibatkan terbatasanya komunikasi dan tercapainya aktivitas yang seharusnya ada dalam pembelajaran jasmani. Aji (2020) menjelaskan bahwa terdapat empat kendala dalam dunia pendidikan dimasa pandemi covid-19 yaitu : guru yang terbatas dalam menguasi internet, kuragnya sarana dan prasarana, terbatasnya akses internet, anggran yang kurang siap.

Berdasarkan pemaparan tersebut tentu saja sangat relevan denggan keadaan pembelajaran pendidikan jasmani yang dilakukan secara daring diseklah saat ini. Selain itu pembelajaran daring lebih banyak memberikan pemahaman secara teori dan juga tertulis yang mana tidak semua peserta didik mampu dengan cepat menyerap materi yang disampaikan guru. Oleh karena itu diharapkan segera ada solusi menenai pandemi covid-19 sehingga pembelajaran dapat dilakukan secra tatap muka kembali.

\section{Kesimpulan}

Berdasarkan hasil penelitian yang dilakukan peneliti dengan judul kepuasan siswa terhadap penggunaan google classroom sebagai media pembelajaran pendidikan jasmani pada masa pandemi covid-19 kelas VIII di SMP Negeri 18 Pontianak tahun 2021 . Jumlah total populasi sebanyak 203 orang sedangkan yang menjawab kuisioner sebanyak 139 orang dan dapat diperoleh hasil sebagai berikut : terdapat 11 siswa $(7,91 \%)$ dalam kategori "sangat memuaskan", terdapat 39 siswa (28,06\%) dalam kategori "memuaskan", dan 81 siswa $(58,28 \%)$ dalam kategori "tidak memuaskan", sedangkan 8 siswa $(5,75 \%)$ yang tergolong "sangat tidak memuaskan".

Sehingga dari deskripsi atau sebuah gambaran secara umum dapat disimpulkan bahwa kepuasan siswa terhadap penggunaan google classroom sebagai media pembelajaran pedidikan jasmani pada masa pandemi covid-19 kelas VIII di SMP Negeri 18 Pontianak tahun 2021berada pada kategori "tidak memuasakan".

\section{Saran}

Adapun beberapa saran yang perlu disampaikan sehubungan dengan hasil penelitian ini, antara lain :

Hasil penelitian ini diharapkan dapat dijadikan acuan untuk lebih memperhatikan kesesuian kemampuan dan karakteristik siswa dalam pelaksaan belajar pada masa pandemi covid-19.

Bagi pihak sekolah, diharapkan lebih memperhatikan kesesuaian kemampuan dan karakteristik siswa agar tujuan pembelajaran pendidikan jasmani disekolah dapat optimal dan tercapai.

Bagi guru pendidikan jasmani, sangat diharapkan sebelum mengajar perlu memperhatikan kesesuaian dengan kemampuan dan karakteristik siswa pada masa pandemi covid-19

\section{DAFTAR RUJUKAN}

Aji, R. H. S. (2020). Dampak Covid-19 pada Pendidikan di Indonesia: Sekolah, Keterampilan, dan Proses 
Pembelajaran. Salam: Jurnal Sosial dan Budaya Syar-I, 7(5),395-402.

Corbyn, G. (2019). Google Classroom: 99 Ideas How To Use Google Classroom Effectively. The Ultimate Guide To Learn Google Classroom. Independently Published.

Grossman, S. (2013). Professor Envision Using Google Class in The Classroom.

Kusuma, A, dan Astuti, w. (2019). Analisis Penerapan Media Pembelajarn Bahasa Arab Berbasis Aplikasi Google Classroom. Jurnal Lahjah Arabiyah.
Udiutomo, P. (2011). Analisa Tingkat Kepuasan Siswa terhadap Layanan Program Smart Ekselensia Indonesia Tahun 2011. Jurnal Pendidikan Dompet Dhuafa (Edisi I).

Sopiatin, P. (2010). Manajemen Belajar Berbasis Kepuasan Peserta Didik.Bogor Graha ndonesia.

Sugiyono. (2018). Metode Penulisan Kuantitatif, Kualitatif, dan $R \& D$. Bandung: Alfabeta.

Wijaya, T. ( 2011). Manajemen Kualitas Jasa. Jakarta: PT Indeks. 